\title{
Commanding Doubly-Fed Induction Generator (DFIG) to Decouple Active and Reactive Power for wind energy
}

\author{
Mohamed Amer Hassn Abomahdi ${ }^{1}$, A. K. B hardwaj ${ }^{2}$, Surya Prakash ${ }^{3}$, \\ Mohammad Tariq ${ }^{4}$ \\ ${ }^{I}$ Al-Zawiya University- Faculty of Natural Resources, Libya \\ ${ }^{2,3,4}$ Department of electrical engineering, SHIATS-Deemed University, Allahabad
}

\begin{abstract}
Different electric wind power conversion systems structures can be used based on the converters topologies. A Wind Energy Conversion System (WECS) differs from a conventional power system. The power output of a conventional power plant can be controlled whereas the power output of a WECS depends on the wind. This nature of WECS makes it difficult for analysis, design and management. Various approaches have been developed to study the behavior of WECS.

In this paper, the steady state characteristics of a WECS using doubly fed induction generator (DFIG) is analysed using MATLAB. The dynamic steady-state simulation model of the DFIG is developed using $M A T L A B$. Simulation analysis is performed to investigate a variety of DFIG characteristics, including torquespeed, real and reactive-power over speed characteristics. Based on the analysis, the DFIG operating characteristics are studied.
\end{abstract}

Keywords: Wind Energy Conversion System (WECS), Doubly Fed Induction Generator (DFIG), Simulation, MATLAB

\section{Introduction}

Renewable energy including solar, wind, tidal, small hydro geothermal, refused derived fuel and fuel cell energies is sustainable, reusable and environmentally friendly and clean. With the increasing shortage in fossil fuels, and pollution problems renewable energy has become an important energy source. Among the other renewable energy sources wind energy has proven to be one of the most economical one. Earlier constant speed WECS were proposed to generate constant frequency voltages from the variable wind. However, Variable speed WECS operations can be considered advantageous, because additional energy can be collected as the wind speed increases. Variable speed WECS must use a power electronic converter. They are classified as full power handling WECS and partial power handling WECS. In full power handling WECS, the power converter is in series with the induction or synethronous generator, in order to transform the variable amplitude / frequency voltages into constant amplitude/ frequency voltages and the converter must handle the full power. In a partial power handling WECS, the converter processes only a portion of the total generated power (eg slip power) which poses an advantage in terms of the reduced cost converter of the system and increased efficiency of the system. This paper is focused on partial power handling WECS using DFIG (1-1). A dynamic steady state simulation of WECS is essential to understand the behaviour of WECS [5-9). This paper explores steady- state characteristics of a typical variable speed WECS that uses doubly fed induction generators using MATLAB. A Simulation analysis is performed and a variety of DFIG characteristics including torque speed and real and reactive power over speed characteristics are analysed.

\section{Doubly Fed Induction Generator}

A doubly fed induction machine is basically a standard, wound rotor induction machine with its stator winding directly connected to the gird and its rotor windings connected to the gird and its rotor windings connected to the gird through a converter. The $\mathrm{AC} / \mathrm{DC} / \mathrm{AC}$ Converter is divided to two components the rotor side converter and the grid side converter. These converters are voltage sourced converters that use force commutated power electronic devices to synthesize an AC Voltage from a DC source. A capacitor connected on the DC side acts as the DC voltage source. A coupling inductor is used to connect the grid side converter to the grid. The three phase rotor winding is connected to the rotor side converter by slip rings and brushes and the three phase stator windings are directly connected to the grid. The control system generates the pitch angle command and the voltage command signals $\mathrm{V}_{1}$ and $\mathrm{V}_{\mathrm{ge}}$ for the rotor and grid side converters respectively in order to control the power of the wind turbine, the DC voltage and the reactive power or the voltage at the gird terminals [13]. 


\section{Wind Energy Concersion System}

Figure 1 shows a WECS using DFIG. A wind turbine catches the wind through its rotor blades and transfers it to the rotor hub. The rotor hub is attached to a low speed shaft through a gear box. The high speed shaft drives an electric generator which converts the mechanical energy to electric energy and delivers it to the grid. As the wind speed varies, the power captured, transmitted to the grid also varies.

$$
\begin{gathered}
\mathrm{P}_{\text {wind }=1 / 2} \rho_{\text {air }} \mathrm{A}_{\text {rotor }} \mathrm{p}(\chi, \beta), \mathrm{V}^{3}{ }_{\mathrm{w}}, \\
\chi=\mathrm{R}_{\text {blade }} \mathrm{W}_{\mathrm{m}} / \mathrm{V}_{\mathrm{w}}
\end{gathered}
$$

Where pair is the air density in $\mathrm{Kg} / \mathrm{m}^{3}$. Rotor is the area covered by the rotor blades $\mathrm{C}_{\mathrm{p}}$ is the performance coefficient of the turbine. $V_{w}$ is the wind speed. The performance coefficient $C_{p}$ is a function of the tip speed ratio, and the pitch angle of the rotor blades. It is determined by aerodynamic laws and thus may change from one turbine to other.

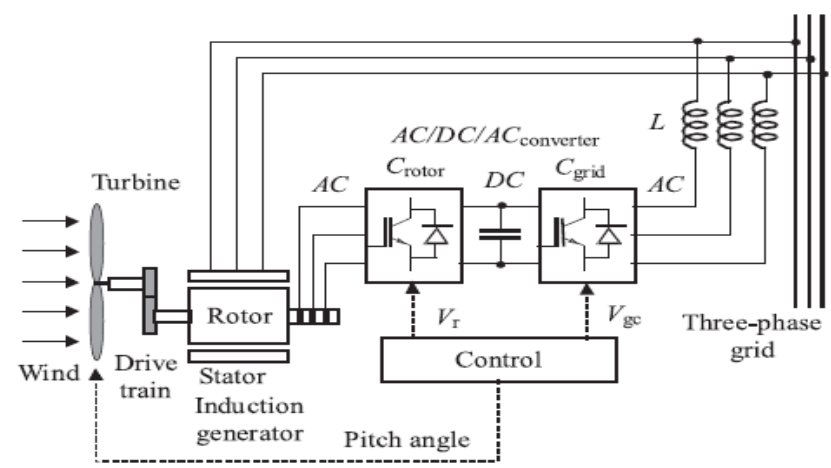

Fig. 1.Wind Energy Conversion System The power output from a wind turbine

\section{Power Flow In Dfig}

Figure 2 shows the Power flow in a DFIG Generally the absolute value of slip is much lower than 1 and consequently the rotor electrical power output $\mathrm{P}_{4}$ is only a fraction of stator real power output Ps. Since the electromagnetic torque $\mathrm{Tm}$ is positive for power generation and since $\mathrm{W}_{\mathrm{s}}$ is positive and constant for a constant frequency grid voltage, the sign of $\mathrm{P}_{\mathrm{r}}$ is a function of the slip sign. Pr is positive for negative slip (speed greater than synchronous speed) and it is negative for positive slip (speed lower than synchronous speed). For super synchronous speed operation, $\mathrm{P}_{\mathrm{r}}$ is transmitted to DC bus capacitor and tends to raise the DC voltage. For sub synchronous speed operation, $\mathrm{P}_{\mathrm{r}}$ is taken out of the DC bus capacitor and tends to decrease the DC bus voltage. The grid side converter is used to generate or absorb the grid electrical power Page in order to keep the DC voltage constant. In steady state for a lossless $\mathrm{AC} / \mathrm{DC} / \mathrm{AC}$ converter $\mathrm{P}_{\mathrm{w}}$ is equal to $\mathrm{Pr}$ and the speed of the wind turbine is determined by the power Reabsorbed or generated by the rotor side converter. By properly controlling the rotor side converter, the voltage measured at the grid terminals can be controlled by controlling the grid side converter DC bus voltage of the capacitor can be regulated.

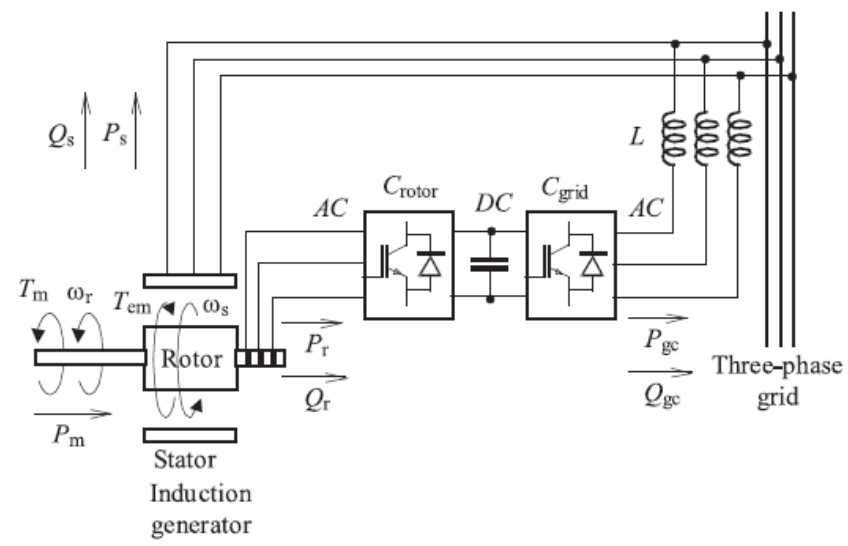

Fig. 2. Power flow in a DFIG 


\section{Dfig Steady State Model}

The induction machine can be represented by the transformer per phase equivalent circuit model where $\mathrm{R} 1$ and $\mathrm{X} 1$ represent rotor resistance and reactance referred to the stator side. The primary internal stator induced voltage $\mathrm{E}_{\mathrm{si}}$ is coupled to the secondary rotor induced voltage $\mathrm{E}_{\mathrm{r}}$ by an ideal transformer with an effective turn ratio $a_{\text {cff. }}$ But the equivalent circuit of Fig. 3 differs from the transformer equivalent circuit primarily in the effects of varying rotor frequency on the rotor voltage $\mathrm{E}_{\mathrm{r}}$. In the case of doubly fed induction machines, however there is a voltage injected into the rotor windings so that the normal induction machine equivalent circuit of Fig. 3 needs to be modified by adding a rotor injected voltage as shown in Fig. 4 [16-20] From the equivalent circuit, for a doubly fed induction machine the real and reactive power of stator $\mathrm{P}_{\mathrm{sw}}, \mathrm{P}_{\mathrm{sQ}}$ and rotor $\mathrm{P}_{\mathrm{r}} \mathrm{W}, \mathrm{P}_{\mathrm{rQ}}$ and the torque developed $\mathrm{Tm}$ can be derived as follows:

$$
\begin{aligned}
& \mathrm{P}_{\mathrm{sw}}=3 \mathrm{~V}_{1} \mathrm{I}_{1} \cos \left(\Phi \mathrm{V}_{1}-\Phi 1_{1}\right) \\
& \mathrm{P}_{\mathrm{sQ}}=3 \mathrm{~V}_{1} \mathrm{I}_{1} \sin \left(\Phi \mathrm{v}_{1}-\Phi 1_{1}\right) \\
& \mathrm{P}_{\mathrm{rw}}=3 \mathrm{~V}_{2} \mathrm{I}_{2} \cos \left(\Phi \mathrm{v}_{2}-\Phi 1_{2}\right) \\
& \mathrm{P}_{\mathrm{rQ}}=3 \mathrm{~V}_{2} \mathrm{I}_{2} \sin \left(\Phi \mathrm{V}_{2}-\Phi 1_{2}\right) \\
& \mathrm{T}=3 \mathrm{E}_{\mathrm{si}} \mathrm{Ir} \cos \left(\Phi \mathrm{E}_{\mathrm{si}}-\Phi 1_{2}\right)
\end{aligned}
$$

Where $V_{1}, I_{i}$ and $V_{2}, I_{2}$ are the effective (RMS) values of the stator and rotor voltage and current respectively.
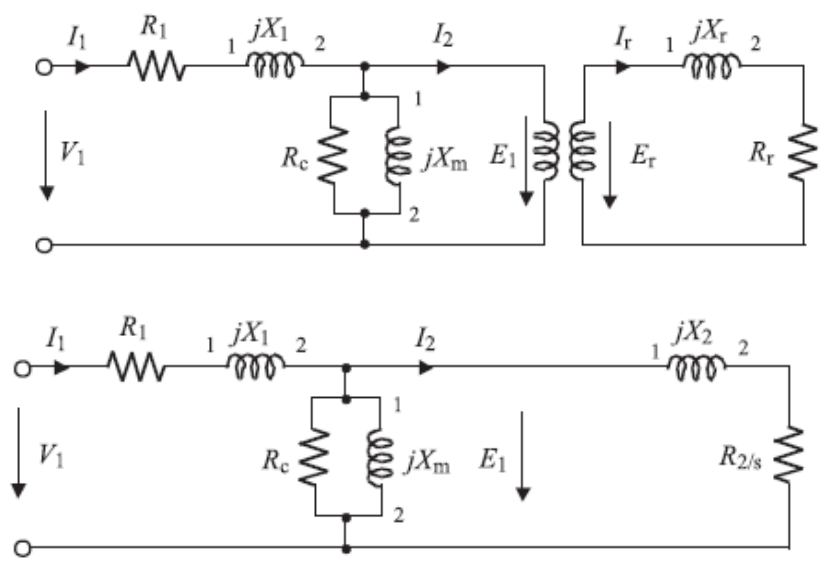

Fig. 3. Conventional induction machine equivalent circuit

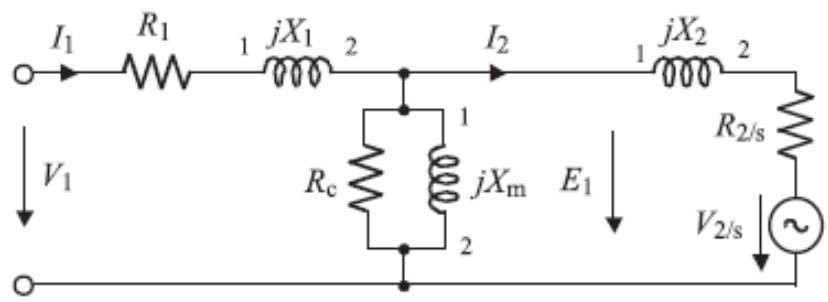

Fig. 4. Equivalent circuit of DFIG

\section{Stator Power}

Stator power generation of a DFIM includes the active and reactive powers sent to the grid through DFIM station winding. A conventional fixed- speed induction generator send sreal power to the grid when driven at speeds above the synchronous speed but also draws inductive reactive power from the grid for its magnetizing and leakage reactive power needs. For a DFIG with an injectived rotor voltage, this characteristic may be changed. The simulation study is conducted by keeping the value of either $\mathrm{V}_{\mathrm{q}}$ or $\mathrm{V}_{\mathrm{d}}$ component constant while varying the other one. Figure 8 shows real power taken from the power supply system by the DFIG as $\mathrm{V}_{\mathrm{d}}$ increases from 0.4 pu to $0.4 \mathrm{pu}$ while $\mathrm{V}_{\mathrm{q}}$ is kept constant at 0.2 pu. Figure 9 shows the DFIG real power as $\mathrm{V}_{\mathrm{q}}$ increases from 0 pu to $0.6 \mathrm{pu}$ while $\mathrm{V}_{\mathrm{d}}$ is kept constant at $0 \mathrm{pu}$.

More simulation results show that DFIG torque speed charactersitics can be shifted or expanded by varying the amplitude of the rotor injected voltage when both $\mathrm{V}_{\mathrm{q}}$ and $\mathrm{V}_{\mathrm{d}}$ are positive. However, the DFIG exhibits a different behaviour From the simulation results, it can be concluded:

1) As either $V_{q}$ or $V_{d}$ component of the rotor injected voltage increases positively, the DFIG real power generation characteristics shifts more into sub- synchronous speed range. 
2) As $V_{q}$ or $V_{d}$ increases positively, the generation pushover power of a DFIG rises too, showing increased DFIG stability and power generation capability and

3) As $V_{d}$ changes from negative to positive, DFIG real power changes gradually from flowing into (motoring) to flowing out of (generating) the induction machine.

A traditional induction machine, takes inductive reactive power from the power supply system for its leakage and magnetizing reactive power needs under both generating and motoring modes. But, this situation is different for a DFIG due to the injected rotor voltage.

Figure 10 to 12 show the DFIG reactive power characteristics. By analyzing the torque, real power and reactive power characteristics as well as many other simulation results, it is obtained that:

1) Increase of $V_{q}$ can result in the expansion of DFIG torque and real power characteristics for its generating mode, it also results in more inductive reactive power needed by the DFIG,

2) The increase of $V_{d}$ not only shifts DFIG torque and real power characteristics to its generating mode but also reduce the DFIG inductive reactive power and even could change it to capacitive.

3) The increase of $V_{d}$ negatively shrinks the DFIG torque and real power characteristics for its generating mode and results in more inductive reactive power need.

It can be concluded from the above analysis that proper coordination between both $\mathrm{V}_{\mathrm{q}}$ and $\mathrm{V}_{\mathrm{d}}$ components of the DFIG injected rotor voltage results in optimal operation of DFIG in terms of torque, real power and reactive power.

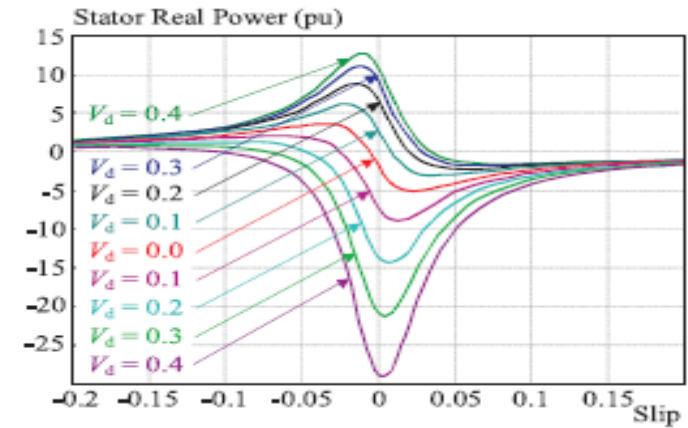

Fig. 5. Simulated DFIG Stator Real Power Characteristics $(\mathrm{Vq}=0.2 \mathrm{pu})$

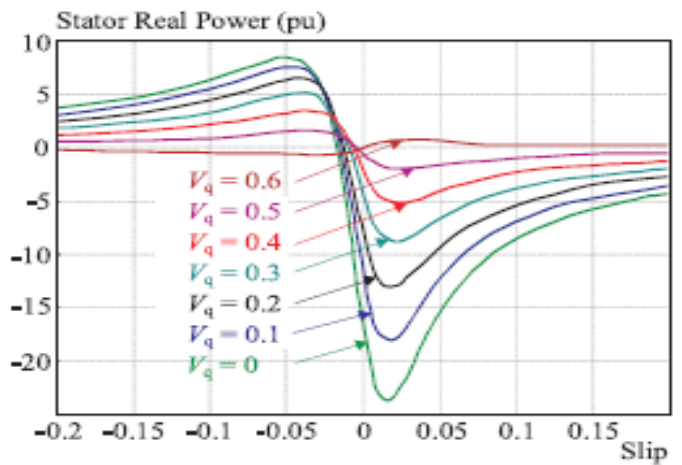

Fig. 6. Simulated DFIG Stator Real Power Characteristics $(\mathrm{Vd}=0 \% \mathrm{pu})$

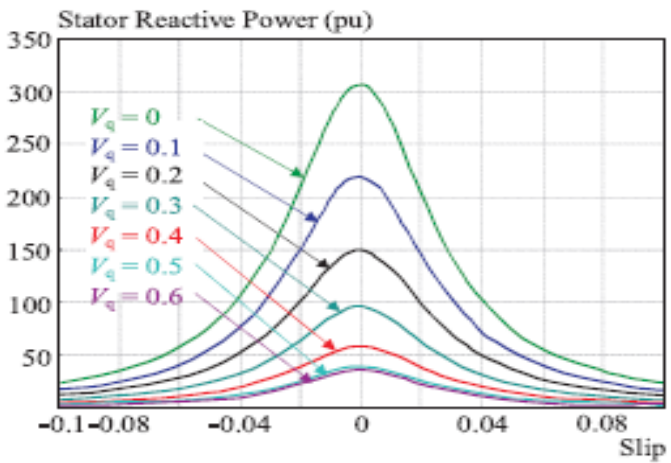

Fig. 7. Simulated DFIG Reactive Power Characteristics $(\mathrm{Vd}=0 \mathrm{pu})$ 


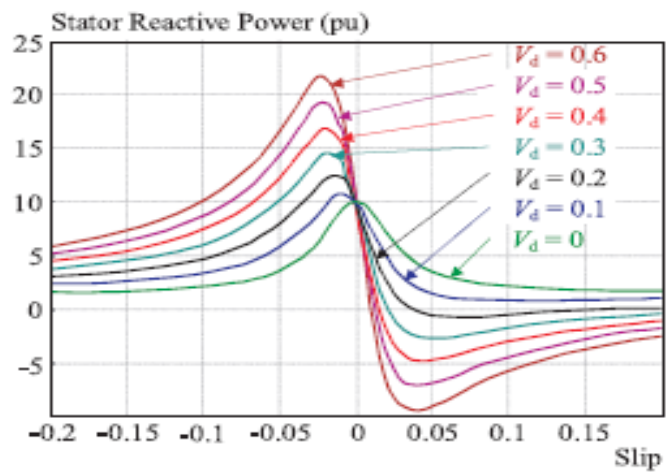

Fig. 8. Simulated DFIG Reactive Power Characteristics $(\mathrm{Vq}=0.2 \mathrm{pu})$

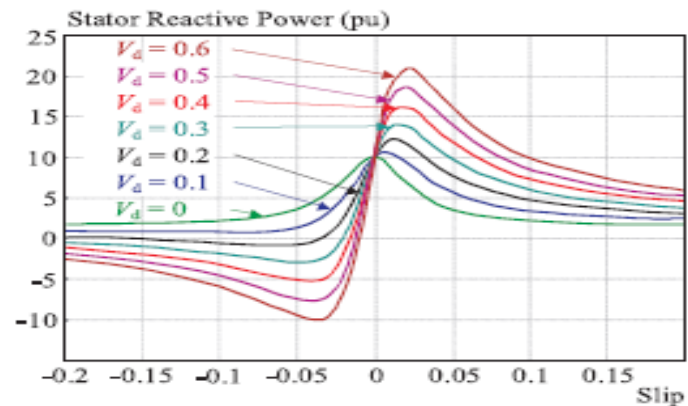

Fig. 9. Simulated DFIG Reactive Power Characteristics $(\mathrm{Vq}=0.2 \mathrm{pu}, \mathrm{Vd}$ negative $)$

\section{Rotor Power Charactertics}

The rotor windings of a conventional fixed- speed wound rotor induction machine are normally shorted by the slip rings so that there is no power output from the rotor of the induction machine. The rotor power under both generator and motor modes are rotor copper loss. For a DFIG, however, the rotor power means not only the rotor copper loss but also real and reactive power passing to the rotor, which is fed to the grid through the DFIG frequency converter.

Figures 13 to 15 show the simulated real power passing to the DFIG rotor, under the conditions of a) $V_{q}=0 \mathrm{pu}$ and $\mathrm{V}_{\mathrm{d}}=0$ to $\left.0.4 \mathrm{pu}, \mathrm{b}\right) \mathrm{Vd}=0.2 \mathrm{pu}$ and $\mathrm{V}_{\mathrm{q}}=0$ to $0.4 \mathrm{pu}$, and c) $\mathrm{V}_{\mathrm{q}}=0.2 \mathrm{pu}$ and $\mathrm{V}_{\mathrm{d}}=0$ to $0.4 \mathrm{pu}$

From the figures, as well as the simulation analysis, it is found that:

1) For both motoring and generating modes, the FDIG sends an additional real power through its rotor to the gird as shown in Fig. 13-15.

2) The characteristics of power sent to the grid through DFIG rotor is mainly dependent on the amplitude of the injected rotor voltage as shown in Figs. 13-15.

3) For high values of the injected rotor voltage, the real power delivered to the DFIG rotor is maximum at synchronous speed at which the DFIG rotor is equivalent to a short circuit. A power control of $V_{q}$ and $V_{d}$ is essential to prevent high currents flowing in the rotor and

4) A comparison between DFIG stator and rotor real power shows that the rotor power is normally smaller than the stator power and the difference between the two really depends on the $V_{q}$ and $V_{d}$ values and the slip.

There is also reactive power passing to the DFIG rotor. Fig. 8 shows the simulated DFIG torque speed and Fig. 9 shows the rotor reactive power speed characteristics under the condition of $\mathrm{V}_{\mathrm{q}}=0 \mathrm{pu}$ and very small increment of $\mathrm{V}_{\mathrm{d}}$. With small increments in the rotor voltage, it can be seen from Fig. 13 how the DFIG torque characteristics change from normal induction machine to DFIM operating condition. The effect of injected rotor voltage on rotor reactive power is clear from Fig. 7 to fig. 9. Basically, when there is no injected rotor voltage, there is no power passing through the rotor to the DFIG frequency converter. As the injected rotor voltage increases slightly, there is reactive power passing through the rotor to the DFIG frequency converts as shown by Fig. 9 from a detailed comparison study it is clear that rotor reactive power is capacitive when the DFIG operates in a generating mode under a sub- synchronous speed and is inductive otherwise. More simulation results, such as Fig. 10 demonstrate that with increased rotor injected voltage; the DFIG shifts more to subsynchronous speed range for its generating mode and the reactive power passing to the DFIG frequency converter is more capacitive. This capacitive reactive power increases the capacitor voltage of the frequency converter. 


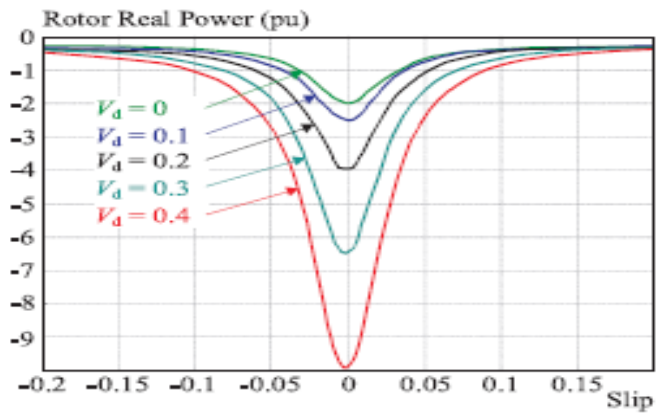

Fig. 10. Simulated DFIG Rotor Real Power Characteristics $(\mathrm{Vq}=0 \mathrm{pu})$

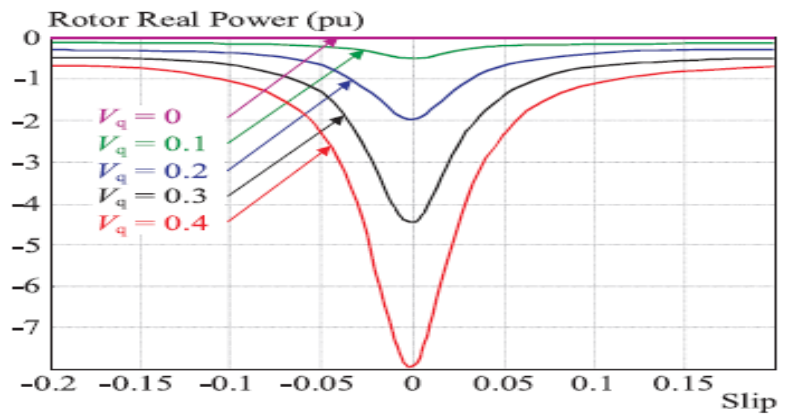

Fig. 11. Simulated DFIG Stator Real Power Characteristics $(\mathrm{Vq}=0.2 \mathrm{pu})$

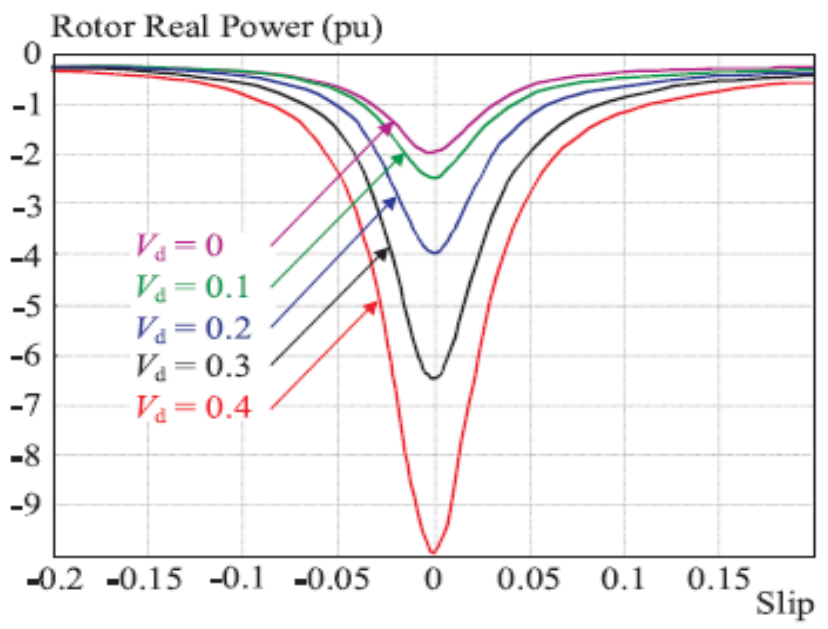

Fig. 12. Simulated DFIG Rotor Real Power Characteristics $(\mathrm{Vq}=0.2$, Vd negative)

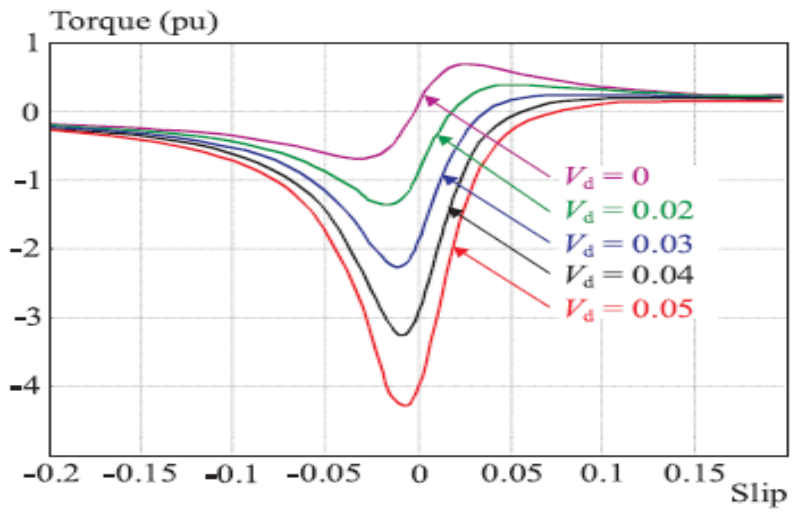

Fig. 13. Simulated DFIG Torque Over Speed (small Vd values) 


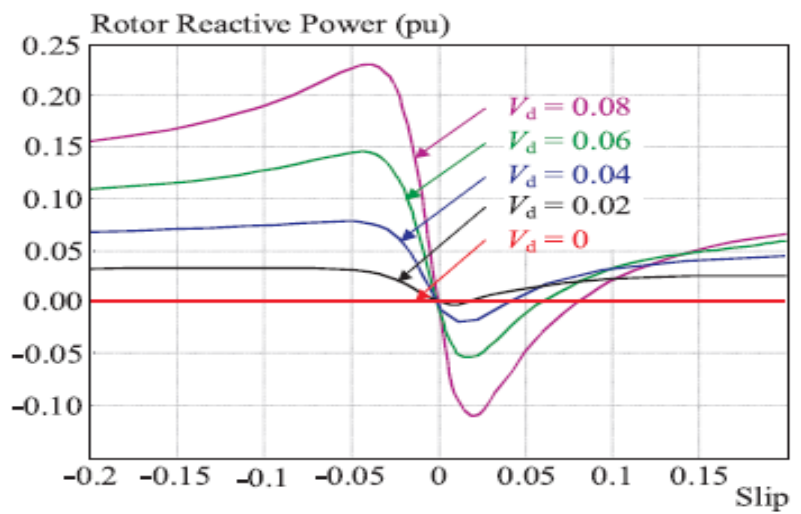

Fig. 14. Simulated DFIG Rotor Reactive Power over Speed (small Vd values)

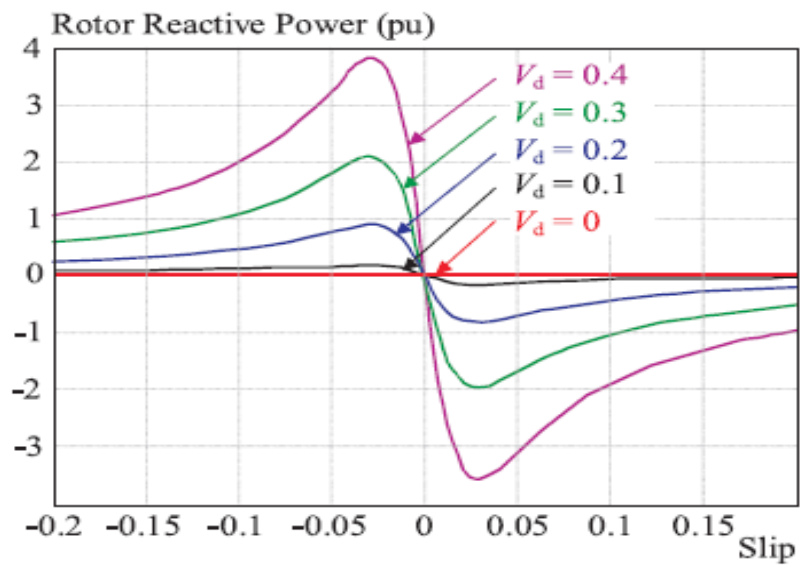

Fig. 15. Simulated DFIG Rotor Reactive Power $\quad$ over Speed $(\mathrm{Vq}=0.2 \mathrm{pu})$

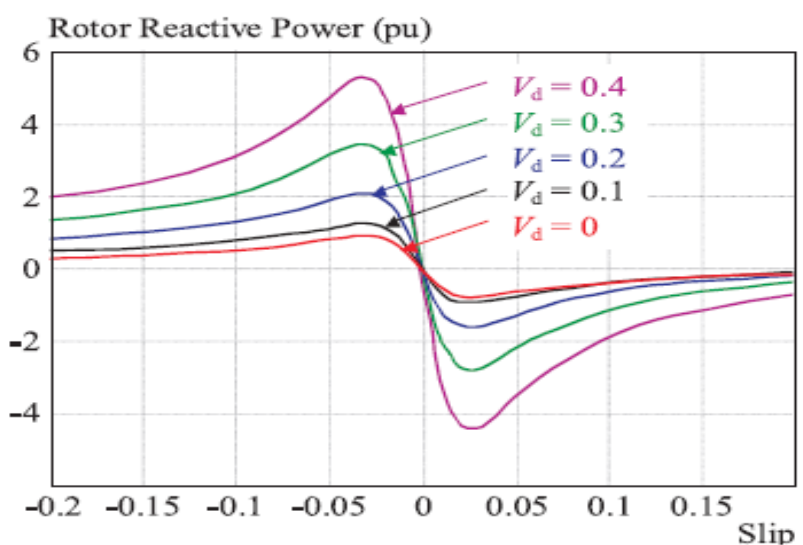

Fig. 16. Simulated DFIG Rotor Reactive Power Over speed $(\mathrm{Vq}=0.4 \mathrm{pu})$

\section{Conclusion}

In this paper a simulation study on the operating characteristics of a doubly fed induction generator is performed using MATLAB.

From the simulation analysis it is clear that the FDIG characteristics are affected by its injected rotor voltage. By varying the amplitude and phase angle of the rotor injected voltage, the DFIG torque speed characteristics are shifted from the over synchronous to sub- synchronous speed range to generate electricity and also increases the DFIG pushover torque, thereby improving the stability of operation.

The simulated stator real power characteristics of the DFIG show that with increase in the rotor injected voltage, the DFIG real power characteristics shifts more into the sub-synchronous speed range and the pushover power of the DFIG rises. 
The increase of $\mathrm{V}_{\mathrm{q}}$ results in the expansion of the DFIG torque and real power characteristics for its generating mode, but at the same time increase the inductive reactive power demand from the grid. Whereas, the increase of $V_{d}$ cannot only expand DFIG torque and real power characteristics for its generating mode but also reduces the DFIG inductive power demand and may even change it to capacitive.

For both motoring and generating modes, the DFIG sends additional real power through its rotor to the grid. Unlike the stator power, the characteristics of rotor power are mainly influenced by the rotor injected voltage. A comparison of the stator and rotor real power shows that the rotor power is normally smaller than the stator power and the different between the two depends on the value of $\mathrm{V}_{\mathrm{d}}$ and $\mathrm{V}_{\mathrm{q}}$ and slip.

It can also be seen that the DFIG rotor power is capacitive when the DFIG operates in the generating mode under a sub synchronous speed and is inductive otherwise.

KVA $2000 \quad$ Rated Voltage $690 \mathrm{~V}$

$\mathrm{R}_{1}$ (stator resistance) $\quad 0.0043 \mathrm{pu}$

$\mathrm{X}_{1}$ (stator reactance) $\quad 0.0809 \mathrm{pu}$

$\mathrm{R}_{2}$ (rotor resistance referred to stator side) $\quad 0.048 \mathrm{pu}$

$\mathrm{X}_{2}$ (rotor reactance referred to stator side) $\quad 0.0871 \mathrm{pu}$

$\mathrm{X}_{\mathrm{m}}$ (magnetizing reactance) $\quad 3.459 \mathrm{pu}$

Frequency $50 \mathrm{H}_{\mathrm{Z}}$

\section{APPENDIX}

\section{References}

[1] PATEL, M. R. : Wind and Solar Power Systems, CRC Press, 1999, pp. 82-83.

[2] ZAVADIL, R.-MILLER, N.-ELLIS, A.-MULJADI, E. : IEEE Power \& Energy Magazine 3 No. 6 (Nov 2005).

[3] BANSAL, R. C.-BHATTI, T. S.-KOTHARI, D. P. : Bibil- iography on the Applications of Induction Generators in Non Conventional Energy Systems, IEEE Transactions on Energy Conversion 18 No. 3 (Sep 2003), 433-439.

[4] DATTA, R.-RANGANATHAN, V. T. : Variable-Speed Wind Power Generation Using Doubly Fed Wound Rotor Induction Machine - A comparison With Alternative Schemes, IEEE Transactions on Energy Conversion 17 No. 3 (Sep 2002 ), $414-421$.

[5] TENNAKOON, A. P.-ARUlAMPALAM, A.-EKANAYA- KE, J. B.-ABEYERATNE, S. G. : Modelling and Control of DFIGs for Wind Energy Applications, First International Con- ference on Industrial Information Systems, Aug 2006 , pp. 8-11.

[6] EKANAYAKE, J. E. : Dynamic Modeling of Doubly Fed In-duction Generator Wind Turbines, IEEE Transactions on Power Systems 18 No. 2 (May 2003), 803-809.

[7] POTAMIANAKIS, E. G.-VOURNAS, C. D. : Aggregation of Wind Farms in Distribution Networks, European Wind Energy Conference and Exhibition, Madrid, June 2003.

[8] FEIJOO, A. E.-CIDRAS, J. : Modeling of Wind Farms in the Load Flow Analysis, IEEE Trans. on Power Systems 15 No. 1 (Feb 2000), 110-115.

[9] KAVASSERI, R. G. : Steady State Analysis of an Induction Generator Infinite Bus System, Proc. IASTED International Conf. on Power and Energy Systems, Marbella, Spain, 2003.

[10] JOHNSON, G. L. : Wind Energy Systems, Prentice-Hall, Upper Saddle River, NJ, 1985

[11] Danish Wind Industry Association, Guided Tour on Wind en- ergy, available from http://www.windpower.org/en/tour/.

[12] FRERIS, L. L. : Wind Energy Conversion System, Prentice Hall, Upper Saddle River, NJ, 1990.

[13] HOPFENSPERGER, B.-ATKINSON, D.-LAKIN, R. A. : Stator Flux Oriented Control of a Cascaded Doubly-Fed In- duction Machine, IEE Proc. Electr.Power Appl. 146 No. 6 (Nov 1999), 597-605.

[14] HANSEN, A. D.-IOV, F.-SORENSEN, P.-BLAABJERG, F. : Overall Control Strategy of Variable Speed Doubly-Fed Induction Generator Wind Turbine, In: Grid Integration and Elec- trical Systems of Wind Turbines and Wind Farms (CD-ROM). NordicWind Power Conference 2004 (NWPC 04), Gteborg (SE), 1-2 Mar 2004 (Chalmers University of Technology, Gteborg, 2004).

[15] MULLER, S.-DEICKE, M.-De DONCKER, R. W. : Doubly Fed Induction Generator Systems for Wind Turbines, IEEE Industry Applications Magazine 8 No. 3 (May/June 2002), 26-33.

[16] KOCH, F. W.-ERLICH, I.-SHEWAREGA, F. : Dynamic Simulation of Large Wind Farms Integrated in A Multi Machine Network, in Proceedings of 2003 IEEE PES General Meeting, Toronto, Canada, July 13-17 2003.

[17] CHAPMAN, S. J. : Electric Machinery Fundamentals, Mc- Graw-Hill Companies, New York, 1999.

[18] YOUSSEF, R. D. : integration of offshore wind farms into the local distribution network, available from http://www.consumer.gov.uk/energy/renewables/ publications/pubs wind.shtml.

[19] KRISHNAN, R. : Electric Motor Drives - Modeling, Analysis, and Control, Prentice Hall, 2001.

[20] MOHAN, N. : Advanced Electric Drives - Analysis, Modeling and Control using Simulink, MN: Minnesota Power Electronics Research \& Education,. 